\title{
sciendo
}

\section{PROTECTION OF THE RIGHTS OF PARTIES, PARTICIPANTS AND THIRD PARTIES DURING ENFORCEMENT IN REPUBLIC OF NORTH MACEDONIA}

\author{
PhD. Cand. Bukurije Etemi-Ademi \\ Faculty of Law, South East European University, North Macedonia \\ be26924@seeu.edu.mk \\ Assoc. Prof. Emine Zendeli \\ Faculty of Law, South East European University, North Macedonia \\ e.zendeli@seeu.edu.mk
}

\begin{abstract}
The aim of this paper is to analyze the protection offered to parties, participants and third parties during enforcement, as one of the most important requirements of the enforcement procedure. Having in mind that bailiffs except for implementing enforcement, they are also competent to determine the means by which creditors' claims will be fulfilled. The realization of the creditors' claims does not mean use of any kind of measure or enforcement procedural activity. In this context the authors review ways in which debtors and their family members can be protected during enforcement actions, such as measures of exclusion and restriction of enforcement on the debtor's items and income. Furthermore, the authors elaborate other legal and important ways for protection of parties, participants and third parties, such as opposition to illegality and complaints provided by the Law on Enforcement.

In this regard, results of this research have shown that the RNM is making efforts to create a more effective enforcement system, which includes guarantees not only for the protection of the creditor and the debtor as a party, but also for the participants and third parties. From the enforcement experiences of citizens were reported dissatisfaction and complaints of citizens
\end{abstract}


regarding the performance of bailiffs, namely taking the necessary means of subsistence form them. To avoid this situation Amendments on the Law on Enforcement in 2020 were brought, so the legal framework was clarified in terms of measures for exclusion and restriction of enforcement. This resulted in the prevention of economic damage of debtors and their family, because now no action can be taken if the debtor has an average salary or pension. Extraordinary legal remedies in enforcement proceeding are excluded, but there are other safeguards that are related to enforcement process but are not regulated by the Law on Enforcement.

Key words: Law on Enforcement, parties and participants, bailiff, legal remedies, restriction, and exclusion

\section{INTRODUCTION}

Enforcement proceedings serve as a method by which the creditor is offered protection by enforcing his claim. In this research we will talk more than just the protection of the creditor and the realization of his claim, given that the claim of the creditor can be fulfilled only under legal preconditions, not violating the rules for the protection of the debtor, but also the interests of participants and third parties. In this regard, the key questions of this research are: What are the probabilities for the realization of the creditor's request, and in what circumstances can it be realized in the RNM? Is the financial existence of the debtor or his family members at risk with the actual framework? What are the guarantees for protection in terms of legal remedies and the possibilities of filing them? These and several other issues, which are important and contribute to the protection of participating parties and third parties in the enforcement process in RNM, will be treated in this paper.

In the past, the concept "protection" was referred only to the protection of the debtor as a natural person within the limits of restrictions and exclusion from enforcement, but this concept did not exhaust only the social dimension, but also the political, economic, and other dimensions (Triva, Belajec, \& Dika, 1980, p. 40). Today, the enforcement activity is limited by the principle of protection of the participating parties and third parties, excluding the undertaking of any kind of procedural activity for the realization of the creditor's request.

In this research we will not only focus on the analysis of the forms by which only the debtor is protected, but also the participants and third parties, including the guarantees of the Law on Enforcement of the RNM and other important international acts. 
Both national legislation and various acts of international character, including the Global Code of Enforcement, call on states to ensure enforcement following international rules, according to which imprisonment for civil debts is prohibited, enforcement against family members of the debtor is prohibited and the interests of children should be respected (Global Code of Enforcement, 2015). The request of the creditor is clear, he demands compulsory implementation of the enforcement document in full and efficiently by the bailiff (Јаневски \& Зороска-Камиловска, 2011, p. 56), while on the other hand we have the interest of the debtors and their families not to have the "existence in economic terms" violated. According to the Recommendations of the Council of Europe, during the enforcement procedure an adequate balance must be struck between the two parties, but also third parties, always considering the provisions of Articles 6 and 8 of the European Convention on Human Rights (Recommendation Rec (2003)17, 2003). In modern enforcement law, efficiency in enforcement is limited by the need to protect the debtor, because the realization of this goal must not question the basic values such as life, dignity, freedom, honor, economic basis, activity, and social existence of debtor (Triva, Belajec, \& Dika, 1980, p. 39).

The issue of the efficiency of the enforcement procedure and cognitive protection has long been the focus of procedural doctrine, enforcement practice and the legislator, but referring only to the integrity, quality, and efficiency of the trial, while legal protection during the enforcement process was considered as a secondary issue (Zoroska-Kamilovska, 2013, p. 448). In the National Strategy for the Integration of the Republic of North Macedonia in the European Union (National strategy for European integration of Republic of Macedonia, 2004), the need for reform of the enforcement system was raised, which introduced the concept of private enforcement. In this regard, the interest and care by various authors to contribute to the construction of the most effective enforcement procedures increased, which would contribute to the protection not only of the creditor, but also the debtor and other participants in the procedure.

Especially misuse of authorizations has not yet taken its rightful place in the scientific literature, abuses that manifest both in the implementation phase and in the determination of enforcement by bailiff. The signal that procedural abuses from bailiffs are present is the lack of justified interest, namely the delay in implementing the enforcement by the bailiff (Петрески, 2020). Therefore, this area should be subject of more frequent analyzes with the purpose of highlighting the forms and ways in which the protection of all entities involved in 
the enforcement procedure can be done, and the latter to be developed according to the rules and provisions that are provided by the Law on Enforcement.

\section{CHARACTERISTICS OF THE ENFORCEMENT PROCEDURE IN REPUBLIC OF NORTH MACEDONIA}

The enforcement procedure by its nature is a very specific procedure. First, we must emphasize that this procedure is not considered as a procedure within which a right is decided, but rather it serves for the enforcement of enforcement documents. This procedure provides protection of the rights for which it has been previously decided in a court procedure, or in another procedure before a competent body. Enforcement means the execution of court decisions and other nonjudicial documents, unfinished titles that oblige the debtor to take an action, inaction (patience) or make a payment (Recommendation Rec (2003)17, 2003). Enforcement activities can be undertaken only in condemnatory decisions, which means that not every decision is subject to enforcement, such as decisions that themselves produce legal effects, decisions that are selfenforcing, declaratory decisions, etc. (Uzelac, 2004, p. 6).

We must make it clear that the enforcement procedure does not constitute a retrial, but neither does it constitute a reinstatement for the same case. The postulate "nulla execution sine titulo", is a consequence of the character and purpose of the enforcement procedure, and this is related to the fact that during the enforcement procedure violent measures are taken against the debtor's property, therefore the creditor's request must be certified with a high degree of security (Јаневски \& Зороска-Камиловска, 2011, p. 42). The definition of these titles in our country is determined by numerus clausus Law on Enforcement.

In general, we are used with the fact that the courts should have the attribute of state violence in the enforcement of decisions, but since 2005 in the RNM this attribute has been passed to private entities. The Law on Enforcement included a wide range of competencies to meet the creditor's claim. The activity according to the nature of the property included enforcement on real estate, movables as well as enforcement of other requests of the debtor or third parties (Triva S., 1968, p. 123). According to Janevski and Kamilovska, since the enforcement is transferred from the competences of the courts and is placed in the competence of the bailiffs, these persons should have legal-public authorizations which can in the same way as the courts apply the forms of forced enforcement (Јаневски \& Зороска-Камиловска, 2011, p. 42). According to Uzelac, private enforcement brings benefits in terms of speed of procedure and efficiency, but on the other hand one must be very careful in implementing and monitoring its 
activity (Uzelac, 2009, p. 83-100).

With the current Law on Enforcement (2016) of the RNM includes two very broad parts: enforcement for fulfillment of monetary claims, and enforcement for fulfillment of nonmonetary claims (Law on Enforcement, Official Gazette of RNM no.72 | 16), while the possibility for submission legal of remedies has rightly remained reserved for the courts. The first part includes enforcement on immovable property, movable property, on the debtor's monetary claims, enforcement on securities, shares in companies, on other property rights, as well as enforcement on requests for delivery or acceptance of movable property or immovable property, while the second part includes the delivery of movable items, delivery and emptying of immovable items, fulfillment of the obligation for action, inaction and patience, return of the employee to work and physical separation of items.

Since the adoption of the Law on Enforcement in 2016, the tendencies were to limit the discretionary spaces of the bailiff, to specify and concretize the legal actions of the bailiffs, to set deadlines so that they are not a source of contradictions in the enforcement practice (Јаневски А., 2006, p. 237). The latter came as a result of the need to avoid the possibility that in enforcement practice different solutions be given to the same issues, all with the aim of unifying enforcement practice, efficiency in enforcement and protection of parties and participants.

\section{PROTECTION OF PARTIES AND PARTICIPANTS DURING ENFORCEMENT}

The bailiff is competent for the implementation of the enforcement (par 1, article 3, Law on Enforcement). $\mathrm{He}$ has the competence in fulfilling the non-monetary and monetary requirements of the creditor. The first paragraph of Article 5 of the Law on Enforcement of the RNM states: "Enforcement for the fulfilment of monetary claims cannot be applied to objects or rights which are necessary for the fulfilment of the basic needs of the debtor and the persons that he according to the law is obliged to maintain, or to carry out the independent activity of the debtor which is the main source of livelihood" (par.1, article 5, Law on Enforcement). This protection initially refers to natural persons and not to legal persons who have the role of debtor in the procedure. The protection provided by this article also refers to the debtor's family members who he has a legal obligation to take care of. Regarding the question why we do not have the exception or restriction of enforcement on non-monetary claims, all authors emphasize that neither the legal provisions provide for such an institution, nor is it necessary because in 
non-monetary claims the manner of fulfilment or objects of enforcement are set out in the enforcement document (Јаневски \& Зороска-Камиловска, 2011, р. 60).

Also Article 4 of the Law on Enforcement attests that: "Execution for fulfillment of monetary demand will be applied in the amount which is necessary for fulfillment of that demand" (Article 4, Law on Enforcement).

This provision indirectly refers to some other provisions that also protect the debtor: what can be the object of enforcement (Article 25), the precise definition of which means can be the object of enforcement for the fulfillment of monetary claims (Article 24), determination of restrictions and exemptions from enforcement (116, 175 and 94), registration of as many objects as are necessary for the fulfillment of the request and procedural expenses (Article 98), protection of the activity of RNM and local self-government units (218), objection to illegality (Article 86), debtor protection (Article 5), etc. (Чавдар \& Чавдар, 2016, p. 36-37). Initially, referring to the debtor's protection, two categories of items are expressed which are exempt from enforcement, but are necessary for him and his family, for example, movable and immovable property and the debtor's income, while the second part contained under the guarantee of Article 5 includes with special emphasis certain debtor's items which serve the debtor for carrying out agricultural or craft activity, although here there is a condition that this activity is the main source of livelihood for him and his family.

If we analyze in detail the second part of Article 5, it says: "During the implementation of the enforcement, the bailiff has the obligation to take into account the dignity and personality of the parties participating in the enforcement procedure and their families, as well as for the enforcement to be more favorable for the debtor" (par. 2, article 5, Law on Enforcement). This part refers to the manner of action of the bailiff, the competencies of the bailiff, as well as the eventual protection in case of non-compliance with the procedural actions. The efforts of the bailiff to carry out the enforcement should be proportional to the request, the means which are expected to be paid, the interests of the debtor, as well as the behavior of the bailiff based on human action, fairness, and respect for the rules of privacy (Чавдар \& Чавдар, 2016, p. 39). These guarantees really ease the position of the debtor, for which the legislator has made a fairly correct solution, long before some countries in the region. For the sake of space, we are quoting only the case of the Law on Enforcement of Kosovo, Article 9, which refers to the protection of the debtor: "During the implementation of the enforcement, attention should be paid to the protection of the debtor's dignity and the enforcement should be as harmless as possible for the debtor" (Law on enforcement of Kosovo, no.04lL-139). Firstly, we know that 
the enforcement hits the debtor's property, but the enforcement is not an activity that causes harm to the debtor. The part of the sentence "as harmless as possible" absolutely does not facilitate the wrong approach to the protection of the debtor as prescribed by the Law on Enforcement in Kosovo.

\section{Exemption from enforcement}

Institutes that are of particular importance in enforcement practice and for which allegations are often made by the public in the RNM are the restriction and exclusion from enforcement. In the legal literature the term exclusion is used in three senses. In the first place is the understanding of the absolute impossibility of carrying out enforcement on certain items, regardless of the purpose, function and quantity of the item; the second meaning represents the relative impossibility of carrying out enforcement on items which have a certain purpose, function or quantity; while the third meaning is the absolute-relative one which implies that the way of using a certain thing makes that thing not be the object of enforcement (Triva, Belajec, \& Dika, 1980, p. 147). The first category according to the authors refers to items that are out of circulation such as mines and other natural assets (Article 206, Law on Enforcement 2016), weapons and equipment intended for protection, state and public security and facilities necessary for the enforcement of criminal sanctions (Article 207, Law on Enforcement), etc. The second category refers to items that may be subject of enforcement, but if they serve to meet the necessary needs of the debtor and family members, then the enforcement cannot be applied to them, while the conditions on when and how they can be implemented is determined by the Law on Enforcement, which we will address below. Regarding the second category, Janevski and Kamilovska emphasize that the best illustration of this concept is using the term "restriction from enforcement", which applies to both the items and the income of the debtor (Јаневски \& Зороска-Камиловска, 2011, р. 97). Finally, the third concept is related to the way items are used, for example, the debtor's funds fall into the category of things that enforcement can be applied to, but not if they will serve the debtor for food and heating.

The bailiff during his activity must first assess which objects and which income are excluded from the enforcement and then draw a conclusion about them, otherwise the debtor has the right to file a legal remedy "objection" by proposing to exclude them from enforcement (Чавдар \& Чавдар, 2016, p. 38-39). The provisions governing the institute of exemption from enforcement are cogent in nature, which means that even if the debtor wishes, he cannot waive the application of these provisions (Јаневски \& Зороска-Камиловска, 2011, p. 105-106). The bailiff must take care of the implementation of these provisions because non-compliance with 
them is illegal in enforcement. With the entry into force of the Law on Enforcement (2016), with the expansion of the circle of persons who can file legal remedies, this automatically expanded the possibility to seek the removal of illegalities from more persons, which largely reflects the protection that is offered in the procedure.

Items that are exempt from enforcement, according to the Law on Enforcement (2016) are food and heating for the needs of the debtor and family members for up to three months; items for personal use, items for basic household needs, furniture, which are necessary for the debtor and members of the debtor's family; food and heating supplies for the debtor and his family members for the next three months; cash advance of the debtor in the monthly amount; medals, memories, wedding rings, personal letters and manuscripts, family photos; tools which serve to help the person with disabilities or motor problems (par. 2, line 1, 2, 5, 6 and 7, article 94, Law on Enforcement). Two other very important categories in the protection of the debtor are the books and items that the debtor needs to perform professional, artistic, or scientific activity, work tools and those for planting, machines, and tools in case of exercise of agricultural and handicraft activities, which represent a necessity to maintain the existence of the debtor and his family members (par. 2, line 3 and 4, article 94, Law on Enforcement). The latter is related to the second part of the guarantees of article 5 of the actual Law on Enforcement for the protection of the debtor, because it refers to the minimum means realized by the debtor, and their families also are sustained by them.

What we need to keep in mind, although it is often not discussed in public and citizens are very little informed, is that in terms of the debtor's items for sufficient food and heating for a period of three months and items for the exercise of agricultural activity and crafts, the exemption rules will not apply when this is provided for in the loan contract concluded with the bank (paragraph 3, Article 94, Law on Enforcement). Regarding the rule of exemption from enforcement on money in line 5 of article 94 Law on Enforcement (cash of the debtor in the monthly amount, which according to the law are exempt from enforcement) the rules of exemption and restriction of enforcement to of the debtor's income will apply, respectively article 116 and 117 of the Law on Enforcement (Чавдар \& Чавдар, 2016, p. 328).

According to article 116 of the actual Law (2016), enforcement can absolutely not be applied on compensations for reduction or loss of ability to work and lost maintenance as a result of the death of the maintenance provider (par.1) ; compensation for bodily injury determined by the provisions of the Law on Disability Insurance (paragraph 2); income from social protection rights "monetary assistance" in accordance with the provisions on social protection (paragraph 
3); means in case of temporary unemployment (paragraph 4); remedies for child protection rights in accordance with the Law on Child Protection (paragraph 5); funds from scholarships, loans and student grants (paragraph 6); income of cadets of the Military Academy of RNM (paragraph 7); compensation for work of convicts in penitentiary institutions (paragraph 8); travel expenses (paragraph 9); seniors' income in accordance with the provisions on social security for the elderly (paragraph 9a); means in the form of humanitarian aid in case of compensation from natural disasters (paragraph 10); funds of the special account of the debtor (paragraph 11) (article 116, Law on Enforcement 2016).

The institute of enforcement has changed in a positive aspect, concretizing the legal framework that avoids abuses in the procedure and the possibility of mistakes during the enforcement. Based on the idea for protection of the debtor in 2018 and 2020 (Official Gazette no. 233\18 and no.14 (20), some changes were made to the Law on Enforcement. The idea of these changes was to express the general and real need for help and support of the most vulnerable categories. These persons are not willingly in a situation where they cannot fulfill their obligations or debts without risking their existence and that of their families, these are people who face existential problems and therefore they must be protected (Правдико, 2020).

\section{Restrictions during implementation of enforcement}

Another institute which is also an expression of the debtor protection in our Law on Enforcement is "restriction on enforcement". In RNM, we can freely categorize the issue of restriction on the debtor's income as the most problematic. We can see this in the Reports of the Ombudsman of the Republic of North Macedonia. In the last report of the Ombudsman of the Republic of North Macedonia in 2019, out of all complaints related to the judiciary, 1/3 of citizens' complaints refer to enforcement (Annual Report of Ombusman, 2020). The ombudsman emphasizes that the restrictions on salaries and pensions provided by the Law on Enforcement, are a very heavy burden because citizens at the same time pay instalments of loans, and this leaves citizens without means of subsistence. Therefore, he proposed legal changes to the restriction on the salary and pension, so that the enforcement can be carried out only over $1 / 3$ of the salary and pension, as well as legal changes to notify citizens before the bank accounts are blocked (Annual Report of Ombusman, 2020).

The enforcement legislation of the RNM categorizes the restrictions on the debtor's income according to the type of creditor's claim that must be enforced. In the first case, priority is given to the creditor's claim in cases of compensation for damage as a result of damage to health, i.e., loss of ability to work and compensation for damage as a result of loss of sustenance due to the 
death of the sustenance provider (par. 1, Article 117, Law on Enforcement 2016). Given the sensitivity and necessity for the enforcement of these requests, the bailiff can implement the enforcement up to $1 / 2$ of salary, pension, and compensations instead of the full salary. The second case of claims are all other claims that do not belong to the first group, to which the bailiff can apply enforcement up to $1 / 3$ of the income that is realized from salary, pension, and compensations instead of salary. This way of regulating the enforcement on the debtor's funds was not enough, because the question arises as to how will the livelihood of those persons who already have a low salary or pension be?

As a protection of the debtors from the second case, the Law on Amending and Supplementing the Law on Enforcement was brought, according to which the citizens receiving: "salary up to the average salary at the time of preparation of the enforcement order, pension up to the average pension, compensation of expenses for accommodation of the person and compensation for care in the foster family, as well as for the children beneficiaries of the family pension, the enforcement is performed up to one fifth of the salary, pension or compensation" (Article 2, Law on Amending and Supplementing the Law on Enforcement 2020). In the transitional provisions of this amendment, the law stipulated that this rule would have retroactive effect, emphasizing that it will be applied to cases initiated not only under the Law on Enforcement of 2016, but also under the Law on Enforcement of 2005.

A very controversial issue which was brought several times before the Constitutional Court of the RNM is the issue of assessing the constitutionality of the provisions of the Law on Enforcement, namely Article 218. This article refers to the protection of the debtor as a legal entity in cases where items and the rights subject to enforcement are owned by the RNM or local self-government units and public enterprises. The idea of this provision is protection in cases when the means to fulfill the enforcement request are necessary for the performance of the activity or duties of the legal person. This is exactly where the Constitutional Court in Decision no. $103 \backslash 2019$ calls upon, adding "Whether the means of the legal person are necessary or not for the performance of the activity or duties of the legal person, is decided by the President of the Basic Court of the unit where the enforcement is performed, namely if the parties fail to reach an agreement" (Decision of Constitutional Court No. 10312019, 2019). In fact, in the content of this decision it is stated that the debt is not repaid but is postponed until the funds reach the account. It is very clear in the Court Decision that these provisions speak of a restriction on enforcement and not an exception. Many dilemmas arise here, such as how much is the state responsible for the way of managing the assets of public entities, how can a 
court president assess whether the entity has assets or not, and the lastly with the statement "The president of the court decides whether the enforcement will be implemented or not" express the culminating point that justifies any criticism of the public opinion, stating that in this case we have an exception from the rule and we do not talk about postponement or restriction. The decision of the Constitutional Court always refers to a situation in which there will not be funds ever and it does not say that "it will be applied to the amount of funds in the account of the legal entity", as it does for all other legal entities!

\section{Legal remedies available to participating parties and third parties}

When the notion of legal remedy is used, usually in the legal literature we refer to the means which serve to oppose the activity undertaken during the enforcement procedure. The words "legal remedy" in enforcement practice mean procedural actions that avoid the negative consequences of decisions and attitudes in enforcement proceedings (Triva, Belajec, \& Dika, 1980, p. 246). Legal remedies are those that serve the parties and participants for protection during the enforcement procedure. These remedies can be divided into remedies provided by Articles 86 and 87 of the Law on Enforcement (objections and appeals), remedies which are provide from other provisions of the Law on Enforcement, and legal remedies provided by other laws, but generally exclude the possibility to file extraordinary legal remedies such as revision and repetition of the procedure (par. 8, article 87, Law on Enforcement 2016).

Objection based on illegality is the most common remedy which is filed in enforcement practice. This is a means through which the request for which the enforcement is carried out is not opposed (it is not an oppositional objection), but it is an opugnational opposition which opposes the action of the bailiff or the inadequacy of the enforcement document that needs to be enforced (Чавдар \& Чавдар, 2016, p. 267-268). The Law on Enforcement does not contain provisions on the circumstances in which the parties may object but leaves room those to be addressed by procedural theory. According to the Law on Enforcement, the objection can be submitted both to the action and to the inaction of the bailiff, within three days, but not longer than three months from the day when he found out about the illegality (in the case of bringing the conclusion for fulfillment, a deadline of 15 days must not pass from its coming to force) (Article 86, par. 1 and 2, Law on Enforcement 2016). The parties, participants and third parties have the opportunity to file this remedy, and they also have the right to appeal the decision made regarding the objection. This is where the legitimacy of the parties comes into play, which consider (believe) or claim that illegality was committed during the enforcement, while these 
allegations are based on facts (legal interest or realization of some right) (Јаневски \& ЗороскаКамиловска, 2011, р. 85).

The question arises as to who should decide on this legal remedy that is so important to the parties. With the reforms in the enforcement sphere brought by the Law on Enforcement of 2005, no matter how much the legislator tried to remove the involvement of the courts in the enforcement sphere, it indisputably "failed" to do so, because there are many provisions which order that some activities be carried out by the courts (Јаневски А. , 2006, p. 236). The same body that has made the decision regarding that issue cannot decide on the legal remedy. The Global Code of Enforcement in Article 22 states that only judges can decide on disputes arising from enforcement (Global Code of Enforcement, 2015). In systems in which almost all jurisdictions are concentrated in the courts, such as in Serbia, the objection is addressed to the same court in which the enforcement takes place, which initially contradicts the constitutional concept of two-tier decision-making (questions the effectiveness of the remedy); secondly, the whole enforcement practice remains at the level of the first-instance courts ( the unity of enforcement practice is questioned) (Šarkić \& Nikolić, 2011, p. 844-845) cited in (ZoroskaKamilovska, 2013, p. 472). In our case, the competence of the President of the Basic Court to decide on the objection was problematic. The deadlines for conducting the adjudication procedure were almost never respected due to the administrative burden he had from his work as court president. Not only such a position was inappropriate but also how much he is specialized in the enforcement field is questionable (Јаневски \& Зороска-Камиловска, 2011, p. 58). After many criticisms and problems which proved that this solution was inefficient, the Law of 2016 transferred this competence to judges according to the annual order of work of the Court (Article 86, paragraph 4, Law on Enforcement).

It is difficult to mention all the forms of protection that are offered in the enforcement process outside the guarantees of Articles 86 and 87, but one thing is clear: they are just as important as objections and appeal. Specifically, one cannot say that the following are less important: the claim for compensation of damage provided by the Law on Enforcement (Article 225); lawsuit against the debtor's debtor for delivery of items (Article 152); lawsuit against the conclusion for sale, and many other situations which are provisions the purpose of which is to provide protection in the proceedings.

As legal remedies, which provide opportunities for protection but do not fall within the enforcement procedural guarantees, the following can also be emphasized: the lawsuit of the 
person who has been unfairly affected in the enforcement procedure; the lawsuit of the conscientious holder of the thing that seeks to prove how much he is allowed to keep the thing until his request is fulfilled; the lawsuit of the third person requesting the confirmation of his property right over which the enforcement has been carried out, etc. (Чавдар \& Чавдар, 2016).

It would be wrong to say that the protection of the participating parties and third parties is provided only through Article 5, 86 or even 87, because the Law on Enforcement in all institutions provides a way through which errors or irregularities which may occur during the enforcement process can be avoided. One such argument is for example counter-enforcement, as a means which is addressed to the creditor for the unjust enrichment of the creditor during the enforcement, in which case the debtor is harmed (Article 88); prohibition of enforcement by the bailiff (exemption of the bailiff, article 44); postponement of enforcement by the creditor more than twice (Article 91), compensation of damage in case of withdrawal of the request for enforcement (Article 29), etc.

Every procedural activity is very important in terms of protecting the rights of the parties and participants. The more concise the legal provisions, the less the possibility of abuse is given to any person involved in the enforcement process, especially the bailiff. Therefore, the Law on Enforcement provides for liability insurance in case of damage from its procedural activity, whereby failure to comply with this provision constitutes a disciplinary violation.

\section{CONCLUSION}

Over the years we have witnessed the efforts of our country to create a legal framework in accordance with international rules to protect the interests of all individuals involved in the enforcement process, especially the debtor. In terms of enforcement practice, accusations are often leveled against the work of bailiffs regarding exclusion and restriction from enforcement. We can easily see this from the complaints addressed to the Ombudsman. Bailiffs before taking steps to stop the assets must provide information about the assets owned by the debtor and especially in blocking the debtor's bank accounts. We consider that the main problem was not so much the limit $1 / 2$ or $1 / 3$, as the issue of how the salary or pension will be taken when he does not have a salary or pension even in the average amount. Recent amendments to the Law on Enforcement in 2020, with rules for restriction in cases where the person has income up to the amount of the average salary and the average pension. This normally contributes in terms of debtor protection, but even here there is room to look at what effects they will have in the future when determining the enforcement by the bailiff. 
Bailiffs in the RNM have quite broad powers, but nevertheless, the control of the actions of bailiffs is in the competence of the courts, which decide on objections for illegality and complaints. In this context, we consider that the involvement of the President of the Court in the enforcement process is unnecessary, therefore the legislator should avoid his involvement in the entire enforcement process.

The concept of protection of parties, participants and third parties in the RNM is a very broad topic, while there is a lot of room for improvement of enforcement practice. The first thing that could be done, is to make sure that bailiffs are careful in their performance both in the implementation of enforcement and in determining the facilities and income of the debtor. It is necessary to increase the cooperation between banks and bailiffs and not to take any steps without having evidence of the source of the debtor's income.

There is a lot to be done and a lot to be addressed, but much more focus is needed on analyzing the current situation in the protection of the debtor, but also other persons involved in enforcement. 


\section{REFERENCES}

1. Annual Report on the degree of provision, prospect, advancement and the protection of human rights and freedoms. (2020, March). Skopje: Ombusman of Republic of North Macedonia.

2. Decision of Costitutional Court No. 103\2019. (2019, November 27). Official Gazette No. 136 on 27.05.2020.

3. Global Code of Enforcement. (2015). International Union of Judicial Officers. Retrieved January 10, 2021, from https://www.uihj.com/downloads/global-code-ofenforcement/\#: :text=The $\% 20$ Global $\% 20$ Code $\% 20$ of $\% 20$ Enforcement,major $\% 20$ inte rnational\%20organisations\%20and\%20institutions.

4. Law on Amending and Supplementing the Law on Enforcement. (n.d.). Official Gazette of RNM no. $14 \mid 2020$.

5. Law on Enforcement 2016. (n.d.). Official Gazette of RNM no.72| 16(72).

6. Law on Enforcement of Kosovo, no.04\L-139. (n.d.).

7. Recommendation Rec(2003)17. (2003, September). Adopted by the Committee of Ministers on 9 September 2003. Retrieved December 17, 2020, from https://search.coe.int/cm/Pages/result_details.aspx?ObjectId=09000016805df135

8. Šarkić, N., \& Nikolić, M. (2011). Kritička analiza pojedinih odredaba novog Zakon o izvršenju i obezbeđenju. Pravni život(11), 844-845.

9. Triva, S. (1968). Riječnik gragjanskog procesnog prava, Novinsko izdavački stamparski i protehnički zavod. Zagreb: Masarykova 1.

10. Triva, S., Belajec, V., \& Dika, M. (1980). Sudsko izvršno pravo. Zagreb: Informator.

11. Uzelac, A. (2004). Improving efficiency of enforcement procedings, Recommendation on enforcement of the Council of Europe and its Relevance for transition countries, Written in support of the European Commission within the framework of Tempus programe. Retrieved March 3, 2021, from http://www.alanuzelac.from.hr/Pdf1/2005Tempus_improving_eff.pdf

12. Uzelac, A. (2009). Privatization of enforcement services, A step forward for countries in transition. Ius Commune Series, 77, 83-100.

13. Zoroska-Kamilovska, T. (2013). Reforme sistema izvršenja u državama regionaKonceptualne sličnosti i razlike, kontroverze i dileme / Reforms of the enforcement system in the countries of the region-Conceptual similarities and differences, controversies and dilemmas. Zbornik radova "Harmonizacija građanskog prava $u$ regionu", 447-477.

14. Јаневски, А., \& Зороска-Камиловска, Т. (2011). Граѓанско процесно правоизврино право / Civil Procedural Law - Enforcement Law (Vol. Книга трета). Скопје: Правен Факултет "Јустинин Први".

15. Јаневски, А. (2006). Новото извршно право на Република Македонија / New enforcement Law in the Republic of Macedonia. Деловно право, 15, 219-238. 
16. Јаневски, А., \& Зороска-Камиловска, Т. (2011). Измените во парничното, вонпарничното и изврното законодавство на Република Македонија во светло на актуелни трендови за забрзување на постапките / Amendments to the contentios, non-contentious and enforcement legislation of the RM. Деловно право, 24, 15-60.

17. Петрески, 3. (2020, Декември 27). Новиот Закон за извршување нуди ефикасност, намалување на трошоците и заштита на најранливите категории. (Е. Павловска, Interviewer) Skopje: Академик. Retrieved January 15, 2021, from https://akademik.mk/noviot-zakon-za-izvrshuvane-nudi-efikasnost-namaluvane-natroshotsite-i-zashtita-na-najranlivite-kategorii/

18. Правдико. (2020, January 8). Retrieved February 20, 2021, from https://www.pravdiko.mk/shto-sodrzhat-predlog-izmenite-vo-zakonot-za-izvrshuvane/

19. Чавдар, К., \& Чавдар, К. (2016). Коментар на законот за извршуване со судска пракса, обрасии за практична примена и предметен регистар, Академик. Скопје: Академик. 